\title{
Experimental method for the assessment and characterization of hazardous waste for long-term storage
}

\author{
GINA ALINA CATRINA, BOGDAN STANESCU*, AGNES SERBANESCU, GEORGIANA \\ CERNICA, LIDIA KIM
}

National Research and Development Institute for Industrial Ecology ECOIND, 57-73 Drumul Podu Dambovitei Street, district 6, 060652, Bucharest, Romania

*Corresponding author: stanescubogdan2@gmail.com

$\begin{array}{lll}\text { Received: } & \text { Accepted: } & \text { Published: } \\ \text { 14.04.2021 } & 10.06 .2021 & 25.06 .2021\end{array}$

\begin{abstract}
Long-term landfilling of hazardous waste should be a careful choice for any producer or generator of waste, as the behavior of the waste is different due to the physical-chemical conditions or following contact with other hazardous waste. In this study, the research undertaken was aimed at developing an experimental method for the assessment and characterization of hazardous waste for long-term storage. The method consists in the assessment of the behavior of heavy metals from waste, under different leaching conditions. To study various hazardous wastes, fly ash from the incineration of medical waste and slag from aluminum casting were chosen. Contact time, $\mathrm{pH}$ and redox potential are important parameters in the leaching process. The solubility of metals increases at $\mathrm{pH}$ values between $2-5 \mathrm{pH}$ units and decreases at $\mathrm{pH}$ values between 6-12 pH units. The highest solubility of metals (As, $\mathrm{Cr}, \mathrm{Cu}, \mathrm{Ni}, \mathrm{Pb}$ and $\mathrm{Zn}$ ) in the tested waste was obtained after 48 hours at $\mathrm{pH}$ values between $2-5 \mathrm{pH}$ units. Also, the values of the redox potential decrease almost linearly as the $\mathrm{pH}$ value increases. The developed method is a useful tool to assess the behavior of hazardous waste for long-term storage in landfills for this category of wastes.
\end{abstract}

Keywords: leaching, hazardous waste, heavy metals, solubility

\section{INTRODUCTION}

Waste generated from industrial activities leads to environmental pollution with heavy metals. Because many wastes contain pollutants from the list of priority hazardous substances, disposal of such wastes should be the last option in the hierarchical order of waste management [1, 2]. Simultaneously with the quality control activities of the deposited waste, the storage landfills must comply with the imposed standards so that the impact on the environmental factors and the human health is minimal $[3,4]$.

Currently, does not exist a specific technology beeing $100 \%$ effective for stabilization of a particular waste type or waste class. The selection of the most appropriate technology is made following of waste characterization and based on laboratory experiments designed to establish the optimal operating parameters [5-9]. The laboratory experiments are based on leaching tests by the standardized method SR EN 12457:2-2003. The results are compared with the limits imposed by MMGA Order no. 95/2005 on establishing acceptance criteria and preliminary procedures for acceptance of waste for disposal [10-14]. The standard leaching method is based on the contact between the solid waste and distilled water or a specific solution for 24 hours. Through this method of leaching, the solubilization process of pollutants from waste is evaluated over time, being determined factors for selecting the type of landfill in which the waste can be deposited $[13,14]$.

For the assessment of hazardous waste in long-term storage, the standardized method CEN/TS 14429: 2005 should be applied. The leaching test provided by this method is particularly important because it provides data on the composition and behavior of waste in long-term storage [15]. 
In the case of metal-containing waste, the stabilization process is influenced by several factors such as: $\mathrm{pH}$ values, chemical speciation, redox potential and adsorption mechanisms [15-21].

The $\mathrm{pH}$ values play a decisive role in stabilizing waste, because the solubility of metals depends on $\mathrm{pH}$. In the case of waste containing metals with different solubilities at the same $\mathrm{pH}$ value, the minimum solubility of each metal species shall be taken into account when choosing the $\mathrm{pH}$ for the leaching test. The increasing $\mathrm{pH}$ leads to the precipitation of metals in the form of hydroxides with low solubility and implicity to obtaining the leachate with a low metals content [7-10]. The redox potential (ORP) is another important parameter considering that in the stabilization processes there are metals with multiple valence states ( $\mathrm{Cr}$, As, Se). In the case of hexavalent chromium (particularly toxic), it must be reduced to trivalent chromium (with ferrous sulphate or sodium bisulphite) which is easily immobilized by $\mathrm{pH}$ control. Thus, the influence of redox potential (ORP) must be studied before selecting the appropriate technology for the stabilization of metal-containing waste $[21,22]$.

Increasing the $\mathrm{pH}$ to maximum values is not a $100 \%$ efficient solution for stabilizing metal species due to the complexity of the waste matrix. Carbonates, silicates, phosphates and other precipitatingcomplexing agents are used to stabilize waste containing heavy metals [22-24].

The experiments performed in this study aimed, on the one hand, to optimize an existing method, in the sense of its development, and on the other hand to implement the method in the current activity of our waste analysis laboratory, to meet those needs to assess dangerous wastes behaviors that are landfilling for a long time periods.

\section{MATERIALS AND METHODS}

\section{Equipment}

Laboratory pH-meter Multi 9430 WTW InoLab

Laser diffraction particle size analyzer Malvern Mastersizer 2000

Ultrapure Water System Millipore Milli-Q

ICP-MS type 7900 Agilent with Mass Hunter 4.4 software

Digestion system Ethos UP, Millestone

\section{Reagents and calibration}

Calibration curves for $\mathrm{As}, \mathrm{Cr}, \mathrm{Cu}, \mathrm{Ni}, \mathrm{Pb}$ and $\mathrm{Zn}$ were preformed using $100 \mathrm{mg} / \mathrm{L}$ Multielement Certified Reference Material, traceable to NIST, containing 23 elements. Quality control of the analytical results was performed with Multielement standard contains 21 elements purchased from VWR Chemicals. All the reagents used in the experiments were of analytical quality grade.

In order to assess and develop the analytical method, two types of waste were chosen. A fly ash from medical waste incineration $(6.35 \mathrm{pH}$ units), noted $\mathrm{P} 1$ and a slag from the casting of aluminum (9.52 pH units), noted P2, were selected.

\section{The method and samples preparation}

The parameters that influence the leaching tests were: $\mathrm{pH}$ of solutions, contact time, solid / liquid ratio, chemical composition of the waste (metals content), particle size of the selected samples ( $\leq 1$ $\mathrm{mm}$ or $\leq 4 \mathrm{~mm})$, stirring speed and working temperature $\left(20 \pm 5^{\circ} \mathrm{C}\right)$.

The amount of dry material and the amount of water to obtain the ratio of 1:10 were selected according to the indications in the standard SR EN 14429:2015 [15]. The volume of acid or of base that was added over the two types of wastes to obtain the desired $\mathrm{pH}$ was also selected according to the same standard.

The method consists in testing the leaching of waste for a period of 48 hours under controlled conditions of time and $\mathrm{pH}($ at $\mathrm{t}=0 ; \mathrm{t}=30 \mathrm{~min} ; \mathrm{t}=2 \mathrm{~h} ; \mathrm{t}=4 \mathrm{~h}, \mathrm{t}=44 \mathrm{~h}$ and $\mathrm{t}=48 \mathrm{~h}$ and $\mathrm{pH}$ between 2 $-12 \mathrm{pH}$ units for each set of time).

The main steps for preparing the waste samples were the following:

a) drying, sieving, weighing; 
b) determination of the acid / base quantity for leaching tests and correction of the samples $\mathrm{pH}$ between 2 and $12 \mathrm{pH}$ units;

c) shaking the samples for 48 hours at 100 rpm on a Shaker stirrer;

d) analysis of specific metals using ICP-MS technique at different contact times between waste and leaching solution $(\mathrm{t}=0 ; \mathrm{t}=30 \mathrm{~min} ; \mathrm{t}=2 \mathrm{~h} ; \mathrm{t}=4 \mathrm{~h}, \mathrm{t}=44 \mathrm{~h}$ and $\mathrm{t}=48 \mathrm{~h})$

e) statistical processing of the obtained results and validation of the method.

To control the quality of the leaching tests, extraction for a waste-free control sample was applied to each set of analyzes.

The general flow scheme for the characterization and evaluation of some contaminants from waste is described in figure 1.

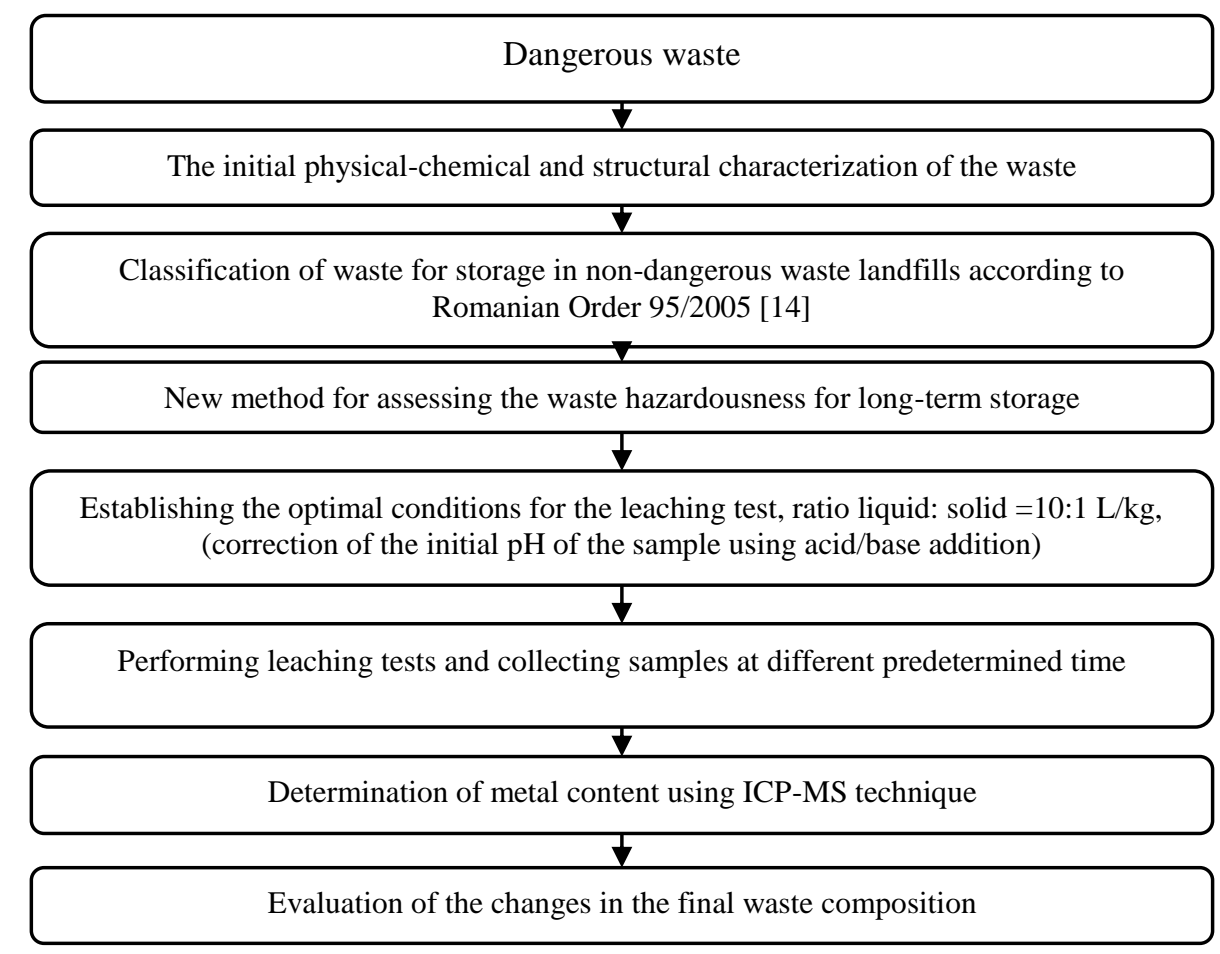

Fig. 1. Flow chart of the experimental method for evaluating contaminants from waste under various leaching conditions

\section{Diggestion step}

After collecting the samples from the leaching tests, the extracts were filtered through a $0.45 \mu \mathrm{m}$ Milipore filter and the liquid was mineralized using a closed microwave digestion system.

For the digestion step, $2 \mathrm{ml}$ of each sample was placed in a digestion vessel over which $7 \mathrm{ml}$ of $\mathrm{HNO}_{3}$ and $3 \mathrm{ml}$ of $\mathrm{HCl}$ were added.

The microwave power was 1600 watts and the temperature was $150^{\circ} \mathrm{C}$. After the digestion stage, the samples were analyzed by ICP-MS for the analysis of heavy metals.

\section{Validation of the method}

The method was in-house validated, by analyzing the 1: 10 leachate resulting after $48 \mathrm{~h}$, at the value of $12 \mathrm{pH}$ units, for both types of samples.

The tested parameters were detection limit (LOD), quantification limit (LOQ), eluting repeatability and leaching test repeatability.

The ICP-MS calibration curve for six metals ( $\mathrm{As}, \mathrm{Cr}, \mathrm{Cu}, \mathrm{Ni}, \mathrm{Pb}, \mathrm{Zn}$ ) was performed in the range of $20 \mu \mathrm{g} / \mathrm{L}$ to $100 \mu \mathrm{g} / \mathrm{L}$. 


\section{RESULTS AND DISCUSSIONS}

Particle size distribution and specific surface area

The particle size was adjusted to assess the hazard time of the deposited waste (grinding to size les than $1 \mathrm{~mm}$ ).

The morphological analysis was performed to highlight the particle size distribution for each sample and to correlate the metal content with the particle size. The smaller the particles, the more accurate the metal leaching test for 48 hours was.

Table 2 shows the values obtained for the specific surface area and the particle size distribution for the two types of waste.

Table 2. Particle size distribution and specific surface area values

\begin{tabular}{l|cccc}
\hline Sample name & $\begin{array}{c}\text { Specific } \\
\text { surface } \\
\left(\mathrm{m}^{2} / \mathrm{g}\right)\end{array}$ & $\begin{array}{c}\text { Particle size distribution } \\
\text { for 10\% of the sample } \\
(\mu \mathrm{m})\end{array}$ & $\begin{array}{c}\text { Particle size distribution } \\
\text { for 50\% of the sample } \\
(\mu \mathrm{m})\end{array}$ & $\begin{array}{c}\text { Particle size distribution } \\
\text { for 90\% of the sample } \\
(\mu \mathrm{m})\end{array}$ \\
\hline P1-initial & 11.1 & 0.345 & 0.640 & 0.948 \\
P1-final & 10.9 & 0.349 & 0.651 & 0.956 \\
P2-initial & 10.1 & 0.389 & 0.654 & 0.951 \\
P2-final & 9.9 & 0.394 & 0.661 & 0.960 \\
\hline
\end{tabular}

P1, P2-initial samples and P1, P2-final samples represents the waste before and after treatment with acid or with base.

In sample P1, $90 \%$ of the particles are smaller than $0.948 \mu \mathrm{m}$, and $50 \%$ of the particles are smaller than $0.640 \mu \mathrm{m}$. (figure 2a) The value of the specific surface changed very little from the initial moment to the final moment after the addition of acid or base (from $11.1 \mathrm{~m}^{2} / \mathrm{g}$ to $10.9 \mathrm{~m}^{2} / \mathrm{g}$ ) (figure $2 b)$.

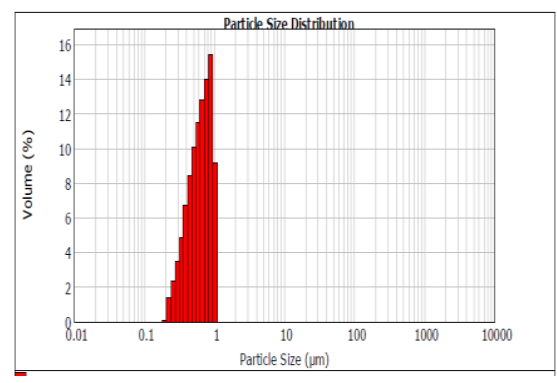

a)

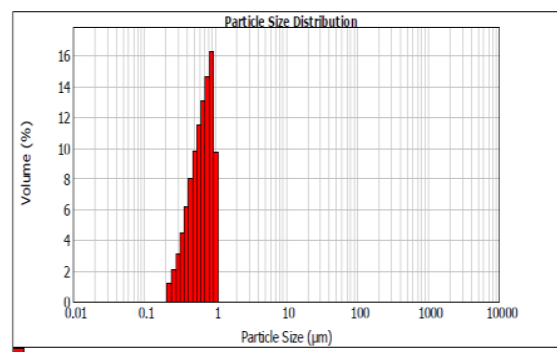

b)

Fig. 2. Particle size distribution in P1 initial (a) and final sample (b)

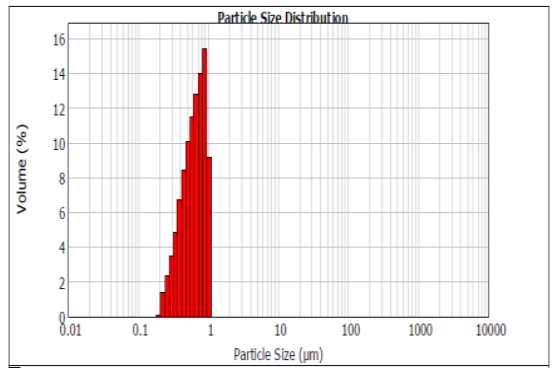

a)

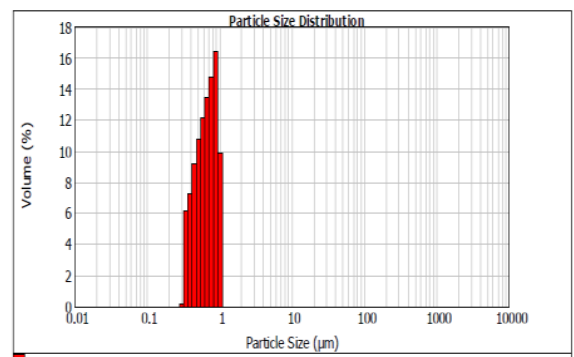

b)

Fig. 3. Particle size distribution in $P 2$ initial (a) and final sample (b)

As in the case of sample P1, for sample P2 the particle size distribution also changed very little (for $90 \%$ of the sample value they changed from the initial moment $(0.951 \mu \mathrm{m})$ to the final moment $(0.960 \mu \mathrm{m})$, insignificant values for the grinding tests (figure $3 \mathrm{~b}$ ).

Based on the morphological analysis (particle size distribution and specific surface area), it was demonstrated that the samples were correctly prepared for the leaching tests. 
In-house validation experiments

In table 3 are presented the values of the performance parameters obtained in the in-house validation experiments using ICP-MS technique for all the analyzed matrices.

Table 3. Performance parameters of the method for leachate from waste P1 and P2

\begin{tabular}{|c|c|c|c|c|c|c|c|c|}
\hline \multirow[b]{2}{*}{ Parameter } & \multicolumn{4}{|c|}{ Leachate from waste $P 1$} & \multicolumn{4}{|c|}{ Leachate from waste $P 2$} \\
\hline & $\begin{array}{l}\text { LOD }^{1} \\
\mathrm{mg} / \mathrm{kg} \\
\text { d.m. }\end{array}$ & $\begin{array}{c}\mathrm{LOQ}^{2} \\
\mathrm{mg} / \mathrm{kg} \\
\text { d.m. }\end{array}$ & $\begin{array}{c}\text { RSDr }^{3} \\
\text { Test } \\
(\%)\end{array}$ & $\begin{array}{c}\text { RSDr }^{4} \\
\text { Eluate } \\
(\%)\end{array}$ & $\begin{array}{c}\text { LOD } \\
\mathrm{mg} / \mathrm{kg} \\
\text { d.m. }\end{array}$ & $\begin{array}{c}\text { LOQ } \\
\mathrm{mg} / \mathrm{kg} \\
\text { d.m. }\end{array}$ & $\begin{array}{c}\text { RSDr } \\
\text { Test } \\
(\%)\end{array}$ & $\begin{array}{c}\text { RSDr } \\
\text { Eluate } \\
(\%)\end{array}$ \\
\hline Arsenic & 0.020 & 0.070 & 6.85 & 4.34 & 0.025 & 0.082 & 5.36 & 4.77 \\
\hline Chromium & 0.004 & 0.013 & 5.67 & 4.86 & 0.008 & 0.027 & 6.65 & 5.72 \\
\hline Cooper & 0.003 & 0.010 & 4.84 & 3.47 & 0.004 & 0.013 & 5.81 & 4.03 \\
\hline Nickel & 0.005 & 0.018 & 6.81 & 5.37 & 0.007 & 0.024 & 5.87 & 4.46 \\
\hline Lead & 0.014 & 0.048 & 7.44 & 5.32 & 0.018 & 0.061 & 6.02 & 5.11 \\
\hline Zinc & 0.004 & 0.013 & 5.79 & 4.97 & 0.006 & 0.019 & 6.55 & 5.05 \\
\hline
\end{tabular}

${ }^{1}$ LOD- detection limit of the analysis method

${ }^{2}$ LOQ- limit of quantification of the analysis method

${ }^{3}$ RSDr Test- standard deviation of repeatability for test analysis.

${ }^{4}$ RSDr Eluate- standard deviation of repeatability for eluate analysis

${ }^{5}$ d.m. - dry matter

The method of evaluation and characterization of some contaminants from hazardous waste is precise, exact, presenting detection limits and small quantification limits for $\mathrm{As}, \mathrm{Cr}, \mathrm{Cu}, \mathrm{Ni}, \mathrm{Pb}$ and Zn by ICP-MS analitycal technique.

Determination of metals in various leaching conditions using ICP-MS technique

The calibration plot for metals were made in the concentrations range $20-100 \mu \mathrm{g} / \mathrm{L}$ using ICP-MS technique. Maximum allowed concentrations (CMAs) according to Order 95/2005 [14] are presented in table 4.

Table 4. CMA according to Order 95/2005 (mg/kg d.m.)

\begin{tabular}{c|cccccc}
\hline Type of landfill & $\mathbf{A s}$ & $\mathbf{C r}$ & $\mathbf{C u}$ & $\mathbf{N i}$ & $\mathbf{P b}$ & $\mathbf{Z n}$ \\
\hline Inert waste & 0.5 & 0.5 & 2 & 0.4 & 0.5 & 4 \\
Non-hazardous waste & 2 & 10 & 50 & 10 & 10 & 50 \\
Hazardous waste & 25 & 70 & 100 & 40 & 50 & 200 \\
\hline
\end{tabular}

dry matter - d.m.

In Figure 4 (a) to (f) are presented the obtained results for different leaching conditions:



(a)

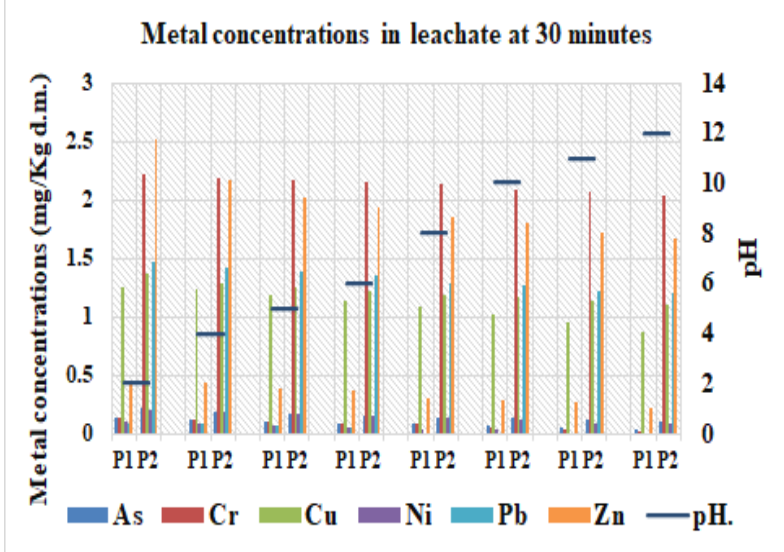

(b) 


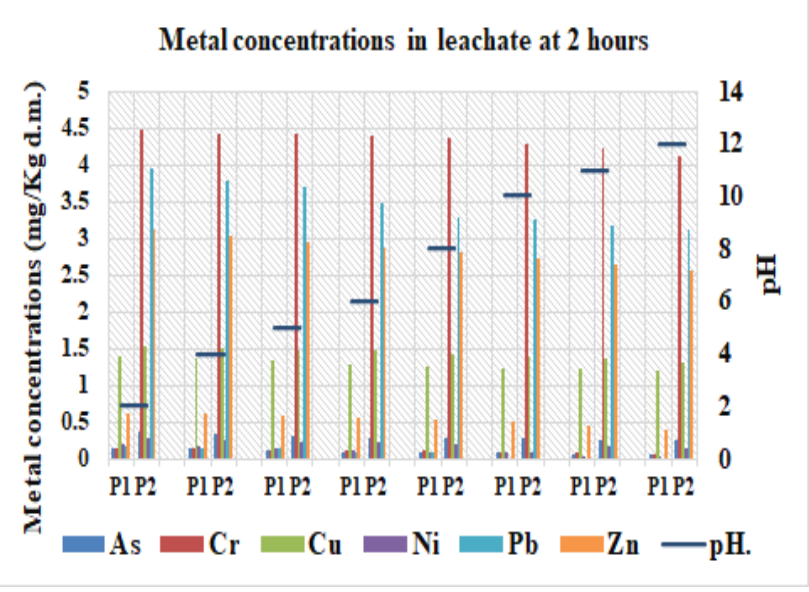

(c)

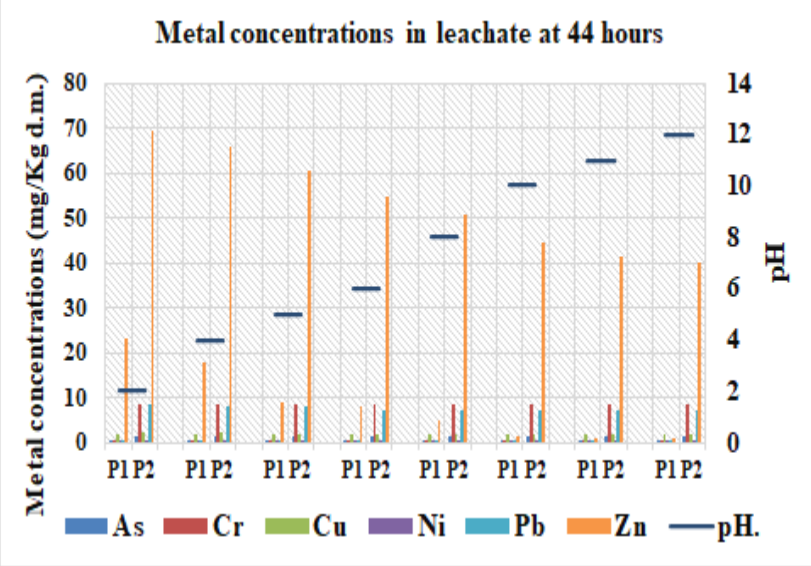

(e)

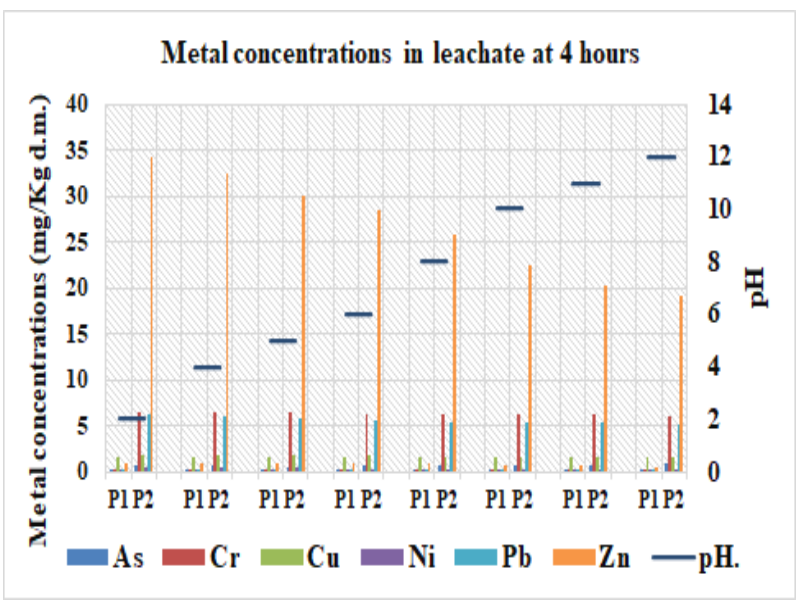

(d)

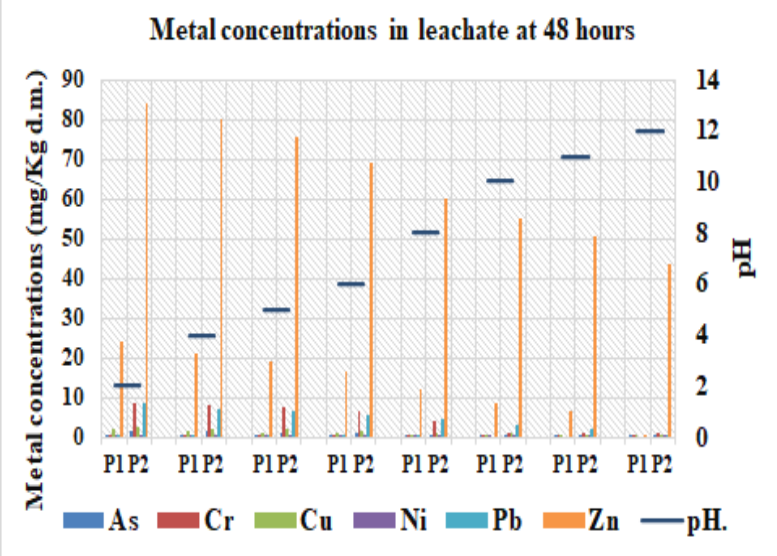

(f)

Fig. 4. Concentration of metals in leachate depending on $\mathrm{pH}$ at different time intervals (a) T0 moment; (b) after 30 minutes; (c) after 2 hours; (d) after 4 hours; (e) after 44 hours;

(f) after 48 hours

From the obtained results it is observed that at T0, after 30 minutes and after 2 hours, the concentrations of the metals in the leachate are not significantly influenced by the contact time and by the $\mathrm{pH}$ variation in the range of $2-12 \mathrm{pH}$ units.

After 4 hours and up to 48 hours, the concentration of metals generally decreases with increasing $\mathrm{pH}$, the most soluble being the $\mathrm{Zn}$ indicator $(\mathrm{pH}=12)$ concentration of $43.43 \mathrm{mg} / \mathrm{kg} \mathrm{d.m}$. (figures $4 \mathrm{a}$ - 4f). For sample $\mathrm{P} 2$, the least soluble metal is nickel $(\mathrm{pH}=12)$, and for sample $\mathrm{P} 1$ the most insoluble metals are nickel and lead (figure 4f).

The increasing order of the concentrations for sample P1 after 48 hours is: $\mathrm{Cu}(1.65 \mathrm{mg} / \mathrm{kg} \mathrm{d.m}$.)> $\mathrm{Zn}(0.74 \mathrm{mg} / \mathrm{kg}$ d.m. $)>\mathrm{Cr}(0.23 \mathrm{mg} / \mathrm{kg}$ d.m. $)>\mathrm{Ca}(0.16 \mathrm{mg} / \mathrm{kg}$ d.m. $)>\mathrm{Ni}(0.15 \mathrm{mg} / \mathrm{kg} \mathrm{d.m.})>\mathrm{Pb}$ $(0.10 \mathrm{mg} / \mathrm{kg}$ d.m.).

The increasing order of the concentrations for the P2 sample after 48 hours is: $\mathrm{Zn}(43.43 \mathrm{mg} / \mathrm{kg}$ d.m. $)>\mathrm{Cr}(8.26 \mathrm{mg} / \mathrm{kg}$ d.m. $)>\mathrm{Pb}(7.22 \mathrm{mg} / \mathrm{kg}$ d.m. $)>\mathrm{Cu}(1.90 \mathrm{mg} / \mathrm{kg} \mathrm{d.m.})>\mathrm{Ca}(1.22 \mathrm{mg} / \mathrm{kg}$ d.m.) $>\mathrm{Ni}(0.31 \mathrm{mg} / \mathrm{kg} \mathrm{d.m.)}$.

Based on the obtained results, it can be stated that the tested samples change their chemical composition only at the end of the leaching time.

The influence of $p H$ on the leaching behavior of metals

In figures 5 and 6 are presented the obtained results for leaching tests according to Order 95/2005 recommendations [14]. 


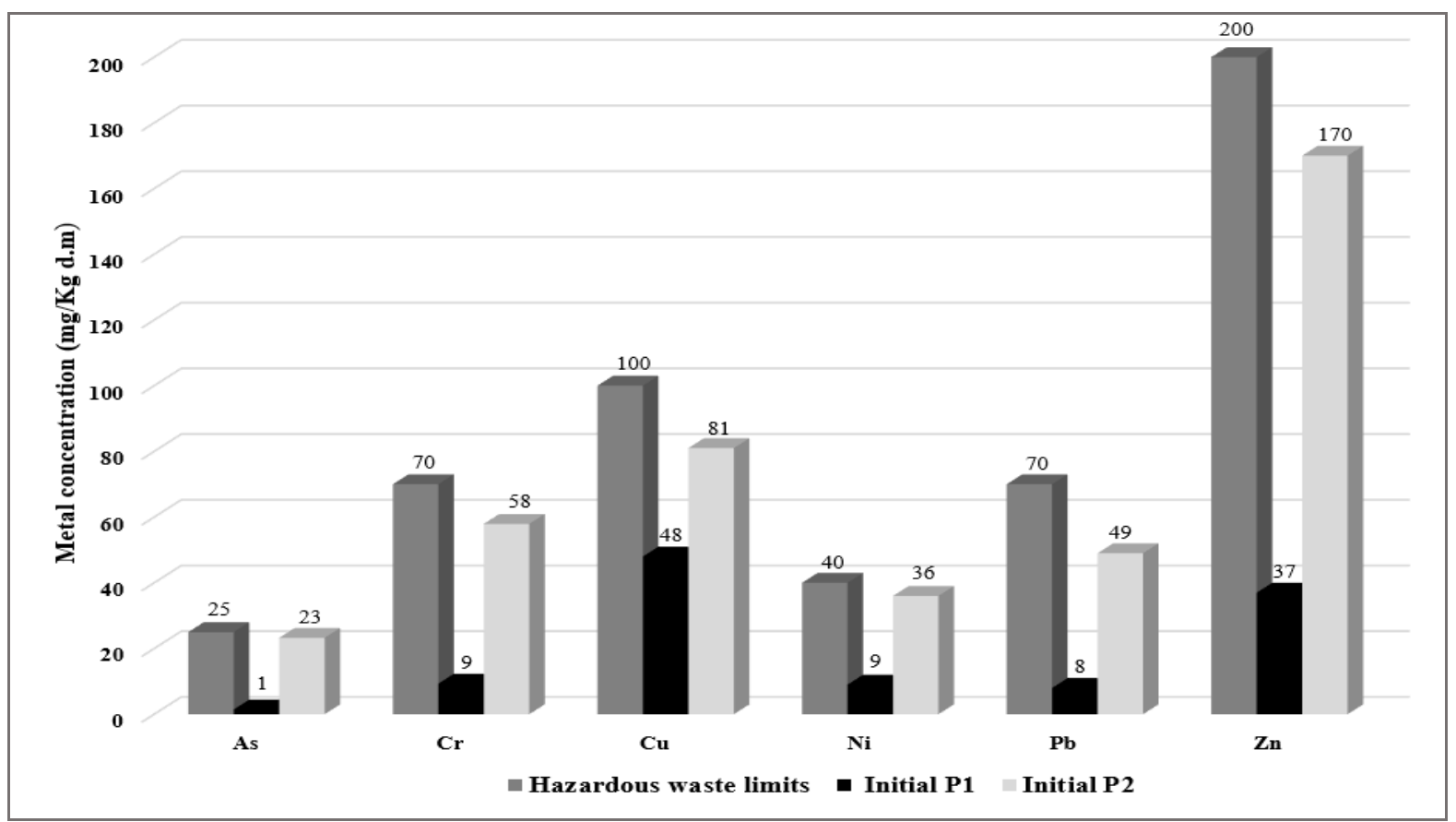

Fig. 5. Leaching tests applied to control samples at the initial $\mathrm{pH}$

At the initial $\mathrm{pH}, \mathrm{P} 1$ sample waste type could be stored in non-dangerous waste landfills and the P2 waste type could be stored in dangerous waste landfills (figure 5) according to Romanian in force legislation [14].

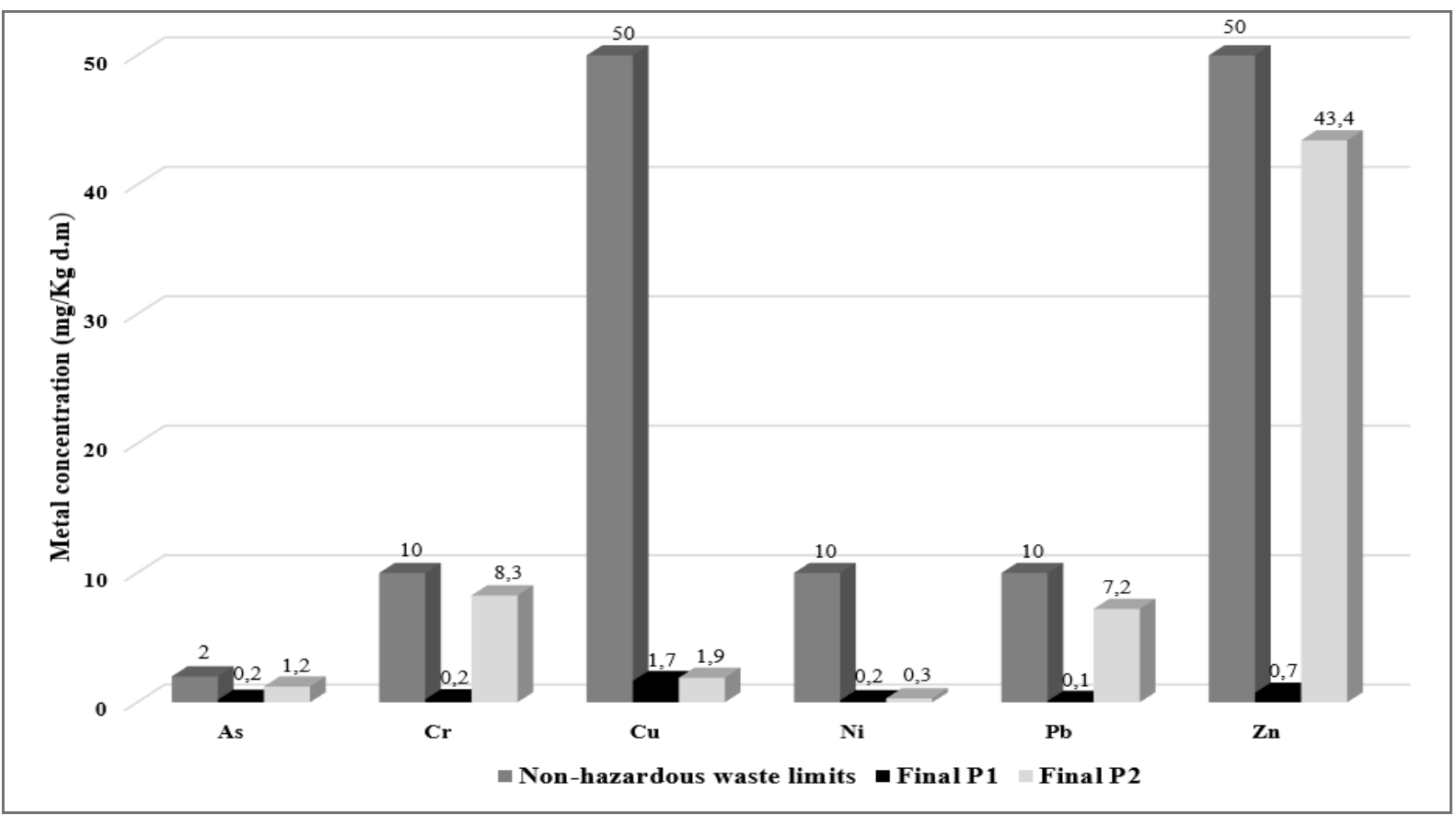

Fig. 6. Leaching tests applied to control samples at $\mathrm{pH}=12$

By changing the $\mathrm{pH}$, the leachate of the tested wastes changed their chemical composition and implicitly the classification criteria for storage. At $\mathrm{pH}=12$, P1 waste sample type could be storage in inert waste landfills, while and P2 waste type sample could be preserve in non-hazardous waste landfills (figure 6). 
In Figure 7 are presented the obtained results for Redox Potential (ORP) before and after treatment.

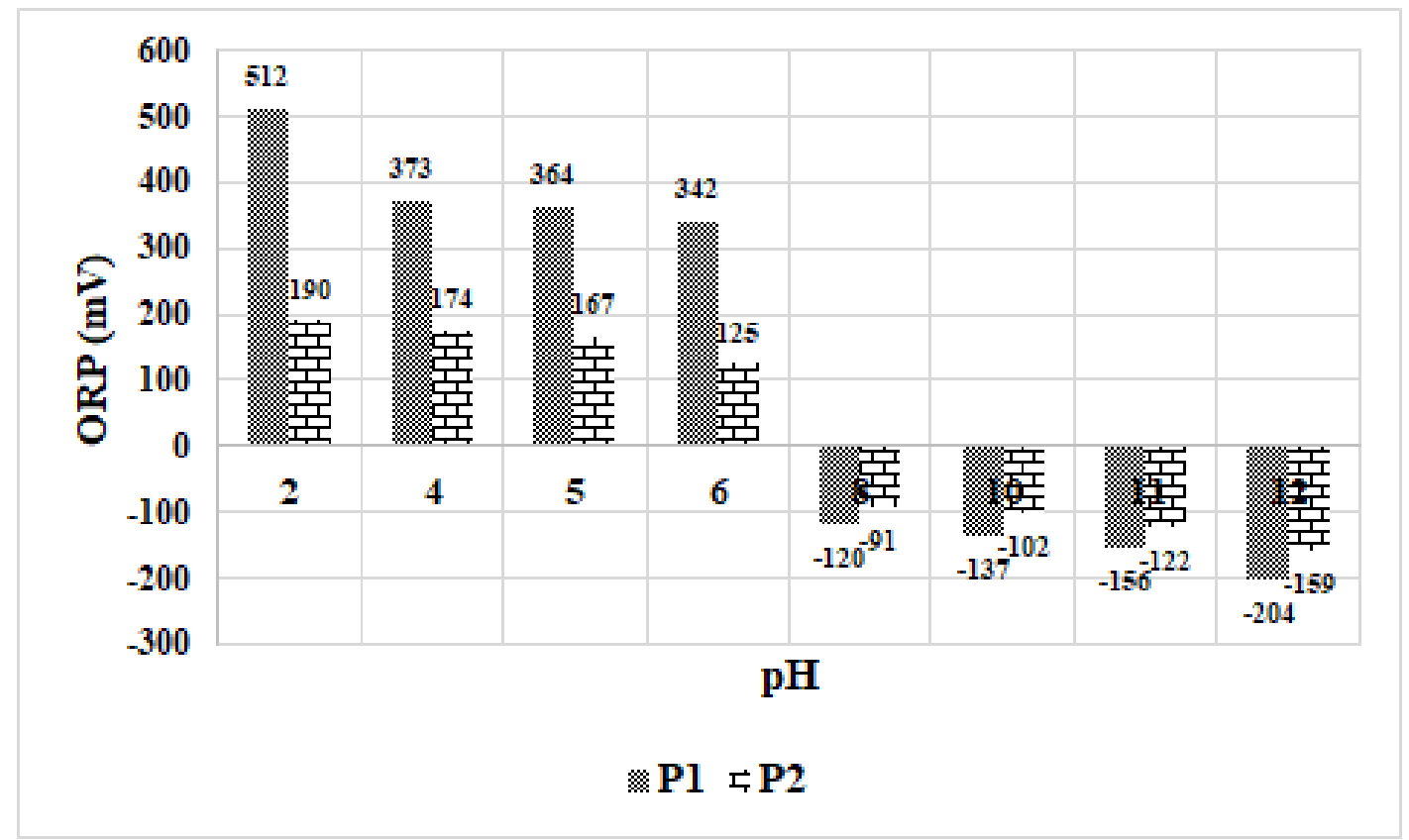

Fig. 7. Redox Potential as a $\mathrm{pH}$ function for $\mathrm{P} 1$ and $\mathrm{P} 2$ leachate solutions

The values of the Redox Potential indicate the following aspects:

a) at $\mathrm{pH}$ between 2-6 $\mathrm{pH}$ units, the concentration of cations (metals) in the leachate increases and the charge of the Redox Potential becomes positive (figure 7).

b) at $\mathrm{pH}$ between $7-12 \mathrm{pH}$ units, the concentration of anions $\left(\mathrm{SO}_{4}{ }^{2-}\right.$, chlorides, bromides, $\mathrm{PO}_{4}{ }^{2-}$, carbonates, bicarbonates, nitrates, etc.) in the leachate increases, and the charge of the Redox Potential becomes negative (figure 7).

The waste leachate could have both oxidizing and reducing properties when $\mathrm{pH}$ was adjusted in the range between 2-12 $\mathrm{pH}$ units.

After 48 hours of contact between aqueous solution and solid waste it was observed a increasing tendency of the Redox Potential due to anions complexation. As a result of the composition changes, the Redox Potential changes its electric charge, presenting a negative value. After 48 hours, small variation of the $\mathrm{pH}$ were observed.

The ORP value has an important role in the leaching process. The absence of oxygen leads to the formation of different chemical phases with significantly different solubilities compared to environmental conditions.

\section{CONCLUSIONS}

In the present study, a series of experiments were performed for the characterization and classification of two different types of waste, in accordance with Romanian Order 95/2005, simultaneously with an evaluation and optimization of the analytical method to highlight the longterm hazard of hazardous waste storage.

Based on the obtained results, it can be concluded that the metal concentration is directly influenced by the $\mathrm{pH}$ value, the contact time and the redox potential of the leachate. As the $\mathrm{pH}$ value increases from 2 to $12 \mathrm{pH}$ units, the concentration of metals decreases. A precipitation potential of all leachate anions and cations was also identified, which is highlighted by measuring the redox potential (ORP).

The 24-hour leaching test for the initial $\mathrm{pH}$ of the waste is not sufficient to assess hazardous waste for long-term storage of waste. For these reasons, the 48-hour leaching test method has been developed and implemented at the laboratory level to assess the hazard of waste in the case of long- 
term storage. Both leaching tests ( $24 \mathrm{~h}$ and $48 \mathrm{~h}$ ) should be used, together or consecutively, for better characterization and evaluation of waste under different environmental conditions.

It is known that waste has characteristics and chemical composition that can change during landfilling conditions, the method developed and presented in this paper is a useful tool for characterizing hazardous waste.

\section{ACKNOWLEDGEMENTS}

This work was carried out through the Nucleu Program, financed by the Ministry of Research and Innovation, through contract 20N/2019, project code: PN 19040401.

\section{REFERENCES}

[1] CAPPUYNS, V., SWENNEN, R., Water Air Soil Pollut, 2008, 191, p. 95.

[2] QUINA, M.J., BORDADO, J. C.M.,. QUINTA-FERREIRA, R. M, Waste Management 2009, 29, p. 2483.

[3] TIWARI, M.K., BAJPAI, S., DEWANGAN, U.K., TAMRAKAR, K.R., J. Radiat. Res. Appl. Sci., 2015, 8, p. 523.

[4] RAJOR, A., XAXA, M., KUNAL, R.M., J. Environ. Manage, 2012, 108, p. 36.

[5] HU, Y., ZHANG, P., Li, J., CHEN, D., J. Hazard. Mater., 2015, 299, p. 149.

[6] KOMONWEERAKET, K., CETIN, B., AYDILEK, A.H., BENSON, C.H., EDIL TUNCER, B., Fuel, 2015, 140, p.788.

[7] KALEMBKIEWICZ, J., SITARZ-PALCZAK, E., J. Ecol. Eng., 2015, 16, no.1, p. 67.

[8] CUI, Y., CHEN, J., ZHANG, Y., PENG, D., HUANG, T., SUN, C., Int. J. Environ. Res. Public Health, 2019, 16, 2046, p. 2.

[9] YOU, G-S., AHN, J.-W., HAN, G-C., CHO, H.C., Korean J. Chem. Eng., 2006, 23, no. 2, p. 237.

[10] SUN, C., CHEN, J., TIAN, K., PENG, D., LIAO, X., WU, X., Int. J. Environ. Res. Public Health 2019, 16, p. 1297.

[11] ZHU, X., LI,W., GUAN, X., J. Hazard. Mater., 2015, 286, p. 85.

[12] MUDD, G.M., WEAVER, T.R., KODIKARA, J., J. Environ. Eng. 2004, 130, p. 1514.

[13] SR EN 12457:2-2003 - Waste characterization. Leaching. Conformity check for leaching granular waste and sludge. Part 2: One stage batch test at a solid-liquid ratio of $10 \mathrm{l} / \mathrm{kg}$ for materials with a particle size of less than $4 \mathrm{~mm}$ (without or with a reduction in size), Romanian Standard Association, https://magazin.asro.ro/ro/standard/73584.

[14] ORDER 95:2005, The criteria for the acceptance and preliminary acceptance procedures for waste at storage and national list of waste accepted in each class of waste landfill, Official Monitor of Romania, Part 1, no. 194/8.

[15] SR EN 14429:2015 - Characterization of waste. Leaching behaviour tests. Influence of pH on leaching with initial acid/base addition, Romanian Standard Association,

https://magazin.asro.ro/Search?q=14429.

[16] KIM, L., ARAMA, G.M., CUCIUREANU, A., GUTA, D., J. Environ. Eng. Manag., 2018, 17, no. 12 , p. 2945.

[17] KIM, L., ARAMA, G.M., J. Environ. Eng. Manag., 2018, 17, no. 9, p. 2201.

[18] KIM, L., ARAMA, G.M., BATRINESCU G., BRATU, M., SERBANESCU, A., LEHR, C.B., Rom. J. Ecol. Environ. Chem., 2020, 2, no. 1, p. 54.

[19] MARIN, N.M., VASILE, G., SIMION, M., PASCU, L.F., LEHR, C.B., Scientific Study and Research: Chemistry and Chemical Engineering, Biotechnology, Food Industry, 2017, 1, no.18, p. 45.

[20] MARIN, N.M., SIMION, M., PASCU, L.F., Proceedings of $19^{\text {th }}$ International Symposium on The Environment and the Industry, 2016, p. 127 
[21] SR EN 15933:2013 - Sludge, treated biowaste and soil, pH determination.

[22] SR EN 16171:2017 - Sludge, treated biowaste and soil, Determination of elements by inductively coupled plasma mass spectrometry (ICP-MS).

[23] U.S. EPA -2010 -Municipal Solid Waste Generation, Recycling, and Disposal in the United States: Facts and Figures for 2010.| United States Environmental Protection Agency, Washington, DC.

[24] U.S. EPA, Leaching Environmental Assessment Framework (LEAF) How-To Guide/ Developing Leaching Evaluations using LEAF, SW-846 Update VI, October 2017, p.72.

Citation: Catrina G.A., Stanescu B., Serbanescu A., Cernica G., Kim L., Experimental method for the assessment and characterization of hazardous waste for long-term storage, Rom. J. Ecol. Environ. Chem., 2021, 3, no. 1, pp. 19-28.

(C) 2021 by the authors. This article is an open access article distributed under the terms and conditions of the Creative Commons Attribution (CC BY) license (http://creativecommons.Org/licenses/by/4.0/). 